\title{
Fragmenty, resztki i przekleństwo archiwum - o nostalgii w kulturze found footage
}

Andrzej Marzec

TEKSTY DRUGIE 2016, NR 2, S. 55-71

DOI: $10.18318 /$ td.2016.2.4

ednomyślna rzeczywistość, czyli jeden świat obiektywnej zgody, niosący ze sobą wygórowane obietnice bezpieczeństwa, spójności oraz sensu, rozsypał się w wielość małych opowieści. Te natomiast niczym w kalejdoskopie wchodzą ze sobą w twórczy konflikt, a żywiąc się raczej poróżnieniem niż porozumieniem, uwalniają nas tym samym skutecznie od przymusu zawsze niesprawiedliwej jedności'. Każda z tych niepozornych, niewielkich narracji, które pod żadnym pozorem nie chcą stać się Historią, wiedzie dzisiaj swój własny, osobny i fragmentaryczny żywot, z dala od marzeń o celowości oraz nadawaniu ludzkiej egzystencji wielkich znaczeń. Wizja świata $\mathrm{w}$ rozsypce, gdzie każdy z rozproszonych okruchów dawno zerwał z całością lub zdążył o niej całkowicie zapomnieć, jeszcze nigdy nie wydawała się tak kusząca, pociągająca i atrakcyjna. Jedynie w tak trudnej do ogarnięcia gęstwinie nieuprzywilejowanych, równoprawnych sensów, mieniących się różnicą oraz iskrzących innością,
Andrzej Marzec - filozof, krytyk filmowy, redaktor "Czasu Kultury", współpracuje z niezależnymi ośrodkami kultury: „Kolektywem 1 A" oraz „Centrum Amarant" w Poznaniu. Jego zainteresowania badawcze skupiają się wokół: dekonstrukcji, widmontologii, estetyki oraz zjawiska "Nowej Fali"we współczesnym kinie greckim. Autor książki Widmontologia. Teoria filozoficzna i praktyka artystyczna ponowoczesności (2015). Kontakt: martius@ amu.edu.pl

1 Zob. J.-F. Lyotard Poróżnienie, przeł. B. Banasiak, Wydawnictwo UJ, Kraków 2010. 
może pojawić się miejsce dla pozostałości - tego, co niekompletne, niepełne i niesamowystarczalne.

Dlaczego współczesna kultura okazuje się tak bardzo przywiązana do swojej przeszłości oraz skoncentrowana na własnych resztkach, które w zadziwiająco krótkim czasie stały się głównym obszarem zainteresowania jej twórców? Chciałbym odnaleźć odpowiedź na to pytanie, przyglądając się artystycznej twórczości found footage, a zwłaszcza pracom Billa Morrisona oraz innych artystów zafascynowanych niezwykle twórczą i produktywną siłą rozkładu. Ten ciekawy gatunek filmowy, nieustannie zapatrzony w przepastne zasoby archiwum, nie tylko wyciąga na światło dzienne ślady nieistniejącej już dawno rzeczywistości, budzi w swoich widzach głębokie poczucie nostalgii oraz wskazuje na słabą obecność przeszłości w teraźniejszości, ale przede wszystkim fetyszyzuje resztki, czyli wszystko to, co udało się choć przez chwilę ocalić przed całkowitym unicestwieniem, przed nieuchronnym destrukcyjnym działaniem czasu.

\section{Życie i twórczość w cieniu archiwum}

Wizualna kultura found footage jest w świadomy sposób wtórna i odtwórcza, gdyż porzuca mit oryginalności oraz rozstaje się z oczekiwaniem nowości, wiązanymi dotychczas z powstawaniem i narodzinami dzieła filmowego. Ten specyficzny rodzaj twórczości opiera się w głównej mierze na mechanizmach cytowania, zawłaszczania i przechwytywania, czyli twórczego łączenia ze sobą już gotowych, istniejących, archiwalnych fragmentów filmów, które nierzadko są ze sobą powiązane tematycznie, wchodzą ze sobą w intertekstualne dyskusje lub też po prostu przenikają się nawzajem. Twórca nie jest w tym przypadku autorem czy reżyserem w tradycyjnym, mocnym tego słowa znaczeniu, lecz odgrywa raczej rolę redaktora, kuratora czy też DJ-a, gdyż posługuje się przede wszystkim zastanym, znalezionym przez siebie materiałem filmowym, a następnie dokonuje jego dowolnej transformacji. Ten swoisty proces twórczy można nazwać za Simonem Reynoldsem przetwórczością (recreativity) $)^{2}$, jednocześnie podkreślając fakt, że zwyczajnie nie sposób wytworzyć dzieła, które zrywałoby z przeszłością i które nie byłoby u niej choć w pewnym stopniu zadłużone. Dlatego, obserwując sztukę filmową z tej mało oryginalnej perspektywy, można stwierdzić, że po prostu jesteśmy skazani na wtórność, natomiast każda nowość okazuje się już zawsze w pewien

2 Zob. S. Reynolds, A. Marzec Retromania, "Czas Kultury” 2013 nr 2, s. 45. 
sposób stara, znoszona i używana (tym razem po prostu w inny, nieznany do tej pory sposób). Zgodnie z przetwórczą wizją rzeczywistości każde „jutro" polega jedynie na innym użyciu „wczoraj", natomiast nie niesie ze sobą upragnionej przez modernizm świeżości, uwalniającej nas raz na zawsze od tego, co minione.

Współczesna kultura, nowa i stara jednocześnie, pozwala nam ostatecznie zwątpić w modernistyczną obietnicę, iluzoryczną opowieść o sterylności. Wprowadza nas w świat, gdzie wszystko okazuje się heterogeniczne, posiada na sobie ślad innego, jest już zawsze tknięte, przechodzone, zabrudzone czyjąś przeszłą obecnością, słowem: staje się nawiedzone ${ }^{3}$. Przetwórczość byłaby zupełnie niemożliwa, gdyby nie rosnąca fascynacja przeszłością oraz powszechna dostępność archiwum, czyli jak twierdzi Jacques Derrida, widmowej przestrzeni wypełnionej śladami innych oraz przeszłymi wolami ży$\mathrm{cia}^{4}$. Jednak zjawisko found footage charakteryzuje się twórczą dowolnością w odróżnieniu od archiwalnego, nierzadko martwego porządku, nad którego nienaruszalnością czuwają według francuskiego filozofa archonci. To oni, pełniąc do tej pory funkcję strażników manuskryptów, nie tylko gwarantowali fizyczne bezpieczeństwo dokumentów, lecz również stali na straży poprawnego ich odczytywania, nienaruszalności sensu, nie pozwalając tym samym na jego rozkład, czyli dowolność wybujałych interpretacji. Derrida zwraca w ten sposób uwagę na instytucjonalną przemoc archiwum, ujawnia jego konserwującą praktykę, która każdy sens potrafi przechowywać jedynie w postaci stosownego zapisu, czyli prawa.

Twórcy filmowi najczęściej nie chcą wcale odgrywać roli archiwistów, polegającej głównie na odkurzaniu i odświeżaniu raz na zawsze ustalonych, ułożonych, zakonserwowanych zbiorów oraz na wiernym reprodukowaniu, odtwarzaniu jednej wizji przeszłości. Nic dziwnego, że nie chcą oddać swojego życia i jednocześnie poświęcić go w służbie martwych praw, lecz raczej starają się ożywić zastany, zastygły porządek, wprowadzić poruszenie do sztucznie wykreowanego świata, który powstał przede wszystkim po to, aby sprzeciwiać się zmianie oraz sile rozkładu. Artyści nierzadko okazują się niechcianymi intruzami w ściśle zorganizowanej przestrzeni archiwum, gdyż swoimi interwencjami burzą i zakłócają gotowy porządek. Swoją aktywnością przypominają niesfornych czytelników, zamieniających miejscami książki

3 Zob. J. Derrida Specters of Marx: The State of the Debt, The Work of Mourning \& the New International, trans. P. Kamuf, Routledge, New York 1994, s. 96.

4 Zob. J. Derrida Archive Fever, trans. E. Prenowitz, "Diacritics” Summer 1995 Vol. 25, No. 2, S. 14. 
w bibliotece. Nie są również archeologami, gdyż nie tworzą systematycznych kolekcji, interesują się wybiórczo znaleziskami, wykorzystując do własnych celów jedynie niektóre $\mathrm{z}$ nich, a inne odrzucając. Budzą tym samym skojarzenia raczej z rabusiami, którzy z niemałą fascynacją zajęci są plądrowaniem archiwów niczym grobowców kultury, w poszukiwaniu cennych i jeszcze nieodkrytych inspiracji dla swoich dzieł.

\section{Obiekt znaleziony}

Bardzo ważnym elementem twórczości found footage jest nie tyle sam proces niemającego końca wyszukiwania materiałów, ile raczej moment znalezienia, czyli wydobycia na światło dzienne czegoś, co nie przestało nigdy istnieć, lecz pozostawało do tej pory ukryte przed wzrokiem innych lub po prostu zostało zapomniane i porzucone. Sam motyw odnalezienia w pierwszej chwili może wywoływać pragnienie autentyczności, wzbudzać wielkie nadzieje dotarcia do oryginału czy też odkrycia historycznej prawdy. Wydaje się jednak, że twórcy filmowi w swoich działaniach dalecy są od tych dążeń, o czym świadczy m.in. ogromna ilość fikcyjnych dokumentów, tzw. mockumentów (mock + documentary), starających się przedstawić i jednocześnie utrwalić wydarzenia, które tak naprawdę nigdy nie zaszły. Prawdopodobnie jedną z głównych motywacji znajdowania zagubionych materiałów filmowych byłaby raczej pełna troski chęć ocalenia, odzyskania przynajmniej w pewnym stopniu tego, co zginęło, i uchronienia przed całkowitym unicestwieniem (wymazaniem z pamięci). Należy podkreślić, że nie chodzi tutaj również o nostalgiczne przywrócenie dawnego świata, pragnienie konserwacji, rekonstrukcji, a tym samym ofiarowania życia wiecznego obrazom, które najczęściej zniszczone i zdeformowane są w fazie głębokiego rozkładu, dlatego stanowią jedynie cień, ślad dawnej rzeczywistości. Ocalenie jest w tym wypadku jedynie chwilowe, dlatego bardzo dobrze zdaje sprawę z materialności i tymczasowości każdego śmiertelnego istnienia.

Postrzeganie sztuki filmowej przez pryzmat tego, co znalezione, zawiesza dotychczasowy podział na filmy archiwalne, których wartość nie ulega wątpliwości, gdyż jest potwierdzona i zagwarantowana instytucjonalnie, oraz na obrazy pochodzące spoza archiwum, zdjęcia amatorskie, nagrania rodzinne, niemające tak wielkiej rangi ${ }^{5}$. Jaimie Baron, dokonując wnikliwej

5 Por. J. Baron The Archive Effect. Found footage and the audiovisual experience of history, Routledge, New York 2014, s. 16. 
analizy i charakterystyki kultury found footage, rezygnuje z tej dualistycznej klasyfikacji, dlatego w swoich rozważaniach decyduje się posługiwać bardziej egalitarnym oraz skutecznym jej zdaniem pojęciem znaleziska (foundness). Według niej obiekt znaleziony zawsze odnosi się do swojego archiwalnego źródła oraz kontekstu, w którym niegdyś funkcjonował i w jakim miał być pierwotnie odczytywany. Archiwalny efekt zdaniem badaczki pojawia się wtedy, gdy widzowie są w stanie bez większego trudu zauważyć różnicę czasu między oglądanym materiałem a ich własną teraźniejszością (rozbieżność czasowa) oraz wówczas, gdy rozpoznają różnicę między pierwotną intencją obrazu oraz jego wtórnym, zupełnie innym użyciem i nowym kontekstem odczytania (rozbieżność intencjonalna) ${ }^{6}$. W przypadku ponownego wykorzystania obrazu, oryginalne zamierzenie autora przestaje obowiązywać, materiał wizualny zostaje zrekontekstualizowany i przywłaszczony, nosi od tej pory ślady całkowicie innej intencji.

Jaimie Baron jednak nie tylko koncentruje się na czysto intelektualnej analizie struktury filmów found footage, lecz podkreśla również ich silne emocjonalne oddziaływanie na widzów. W tym kontekście pisze już nie o archiwalnym efekcie, lecz afekcie, nieodłącznie związanym z pojawiającym się przejmującym i nieodwołalnym poczuciem utraty. Gdy rozpoznajemy na ekranie przeszłą, minioną rzeczywistość, mamy jednocześnie świadomość tego, że oglądamy coś, co już nie istnieje, lub też osobę, która w danej chwili już nie żyje ${ }^{7}$. W związku z tym według Baron o wiele bardziej porusza nas sama wizja utraconego codziennego, prywatnego życia jednostki niż dosłowne przedstawienia masowych grobów czy też anonimowych martwych ciał, gdyż ich indywidualnych historii po prostu nie znamy i nie mamy do nich dostępu.

Znalezione, ocalone przed zaginięciem obrazy, resztki bezpowrotnie minionej rzeczywistości wzbudzają w nas również dojmujące poczucie nostalgii. Można zaryzykować twierdzenie, że współczesna kultura jest przesiąknięta tęsknotą za tym co utracone, o czym świadczą m.in. nadużywane strategie estetyczne vintage i retro. Najciekawsze jest jednak to, że tak naprawdę zupełnie nie wiemy, za czym tęsknimy, co dokładnie straciliśmy i czy właściwie chcielibyśmy albo moglibyśmy w ogóle odzyskać to, o czym tak niewiele wiemy. Svetlana Boym wyróżnia przynajmniej dwa rodzaje współczesnej nostalgii

6 Zob. Tamże, s. 17-30.

7 Zob. Tamże, s. 86-87. 
(restorative/reflexive) $)^{8}$. Pierwszy z nich związany jest z utopijnym pragnieniem przywrócenia, odzyskania i ożywienia przeszłości. W przypadku twórczości filmowej polegałby na konserwacji i cyfrowej obróbce zdjęć, a wszystko po to, aby dać im nieśmiertelność, ocalić idylliczny, a przez to również fikcyjny obraz nienaruszonych w żaden sposób przemijaniem ludzkich dziejów. Ten rodzaj nostalgii, dążący przede wszystkim do ponownego uobecnienia przeszłości w całości, bez żadnej straty oraz ubytku, często wiąże się z powrotem różnych konserwatywnych ideologii oraz nacjonalizmem. Charakteryzuje się ogromną tęsknotą za absolutnym, bezcielesnym oryginałem, dlatego objawia się zdecydowaną niechęcią do wszelkich zmian oraz transformacji związanych z działaniem czasu oraz materialnym rozkładem.

Z kolei drugim uczuciem związanym z przemijaniem, o którym pisze Boym, jest nostalgia refleksyjna, uznająca ludzką skończoność i materialność za niezbędny warunek istnienia. W tym wypadku nie interesuje nas jeden, stały obraz przeszłości, który konserwujemy i otaczamy opieką w naszej wyobraźni, lecz raczej wielość oraz różnorodność jego wersji powstałych w wyniku twórczych procesów rozkładu czy też dekompozycji. Ten rodzaj tęsknoty jest zdecydowanie bliższy koncepcji archiwalnego afektu Baron, a także towarzyszy większości twórców found footage, gdyż to właśnie resztki, fragmenty, pojedyncze kadry, urwane historie fascynują ich najbardziej, a nie nudna, przewidywalna i przede wszystkim nigdy nieosiagalna, iluzoryczna całość.

\section{Odurzeni archiwum}

Charakterystyczną cechą współczesności nie jest już tylko niezwykłe przytłoczenie ciężarem czy też wręcz nadmiarem historii, niepozwalającej się od niej w żaden sposób uwolnić i trzymającej teraźniejszość w szachu . Potrafimy na naszych przenośnych urządzeniach zmieścić całą historię literatury, kina i muzyki, co więcej, jesteśmy w stanie bez żadnego trudu nosić wszędzie te dane ze sobą. Pragnienie bycia odurzonym archiwum stało się dzisiaj czymś zwyczajnym i codziennym. Chcemy tworzyć i pozostawać wciąż pod jego wpływem, gdyż działa na nas niczym substancja odurzająca, a jej uzależniająca obecność wciąż, niezmiennie, utrzymuje się w krwiobiegu kultu-

8 Por. S. Boym The Future of Nostalgia, Basic Books, New York 2001, s. 49.

9 Zob. F. Nietzsche O pożytkach i szkodliwości historii dla życia, w: tegoż Niewczesne rozważania, przeł. M. Łukasiewicz, Wydawnictwo Officyna, Kraków 1996, s. 88. 
ry, przyprawiając jej odbiorców o zawrót głowy. Zgodnie z diagnozą Boym wszyscy zamieszkujący teraźniejszość są zarażeni nieuleczalną tęsknotą za tym, co minione. Stosując jej klasyfikację nostalgii w opisie współczesnego społeczeństwa, można mówić o zachowawczych, konserwatywnych tradycjonalistach (nacjonalistach) lub zainspirowanych dniem wczorajszym, refleksyjnych twórcach (hipsterach). Pierwsi traktują swoje przywiązanie do dziedzictwa oraz wymóg jego reprodukcji niezwykle poważnie, gdyż przepełnieni są wiarą w autentyczność źródła oraz lękiem przed odejściem od czystego oryginału. Natomiast drudzy robią raczej użytek z tradycji, wykorzystują ją do różnorodnych, własnych celów, posługują się nią swobodnie, traktując historię raczej jak ornament czy też część ciekawej autokreacji. Tymczasem każdy z nich bez wyjątku jest podobnie zapatrzony w zazwyczaj nieswoją przeszłość oraz wypełniony tak samo mocną, ale jakże inną w skutkach melancholią. Współczesnych nostalgików oprócz tęsknoty zrównuje także kapitalizm, który obiecuje swoją pomoc w spełnieniu różnorodnych melancholijnych pragnień, oferując szereg produktów retro i otaczając warstwą patyny to wszystko, co zostało przed chwilą wyprodukowane. Jednak system kapitalistyczny, nie będąc w stanie w żaden sposób dotrzymać obietnicy rzeczywistego powrotu do przeszłości, czyni z nas jedynie zapracowanych konsumentów nostalgii.

Życie w cieniu archiwum polega w głównej mierze na tym, że współcześnie mamy ogromne trudności z oceną tego, co warte jest zachowania, a co należy po prostu odrzucić i unicestwić. Zarówno Reynolds ${ }^{10}$, jak i Baron ${ }^{11}$ zgodnie zwracają uwagę na problem braku kryterium archiwizacji, gdy każdy $\mathrm{z}$ nas dysponuje urządzeniami rejestrującymi, chociażby w swoim telefonie. Między innymi dlatego mamy dzisiaj do czynienia z prawdziwą nadprodukcją obrazów. Dosłownie każdej minuty w popularnym serwisie YouTube zostaje zamieszczonych 300 godzin materiałów filmowych, to zdecydowanie zbyt dużo, aby zapoznać się chociaż z częścią z nich w ciągu własnego życia ${ }^{12}$. Duża dowolność, by nie powiedzieć chaotyczność, obecna we współczesnym tworzeniu internetowego archiwum, a także nadmiar zapisywanych danych zdecydowanie osłabiają dotychczasową rolę archontów, którzy według Derridy zajmowali się do tej pory jego kształtowaniem oraz porządkowaniem.

\footnotetext{
10 Zob. S. Reynolds Retromania: Pop Culture's Addiction to Its Own Past, Faber \& Faber, New York 2011.

11 Zob. J. Baron Archive Effect..., s. 16.

12 Zob.https://www.youtube.com/yt/press/statistics.html (31.08.2015)
} 
Współczesne archiwa przestały być wykluczające, tworzone są pod nieobecność archonta (patriarchy), gwaranta odpowiedniej hierarchii, dlatego również charakteryzują się mniejszą instytucjonalną przemocą. Zaskakujący brak strażnika, jego chwilowa słabość, nieprzytomność lub sen pozwoliły na to, aby w uświęconej dotąd przestrzeni archiwum mogły znaleźć się elementy całkiem przypadkowe, codzienne i mało znaczące. Derrida charaktery-

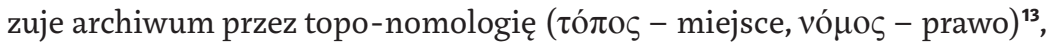
co oznacza, że jego niezbędnym składnikiem jest wyznaczona przestrzeń, w której są przetrzymywane, uwięzione, cenne dokumenty. To właśnie jej cechy oraz granice determinują kształt archiwum i wpływają bezpośrednio na to, co może być w nim przechowywane, czyli archiwizowane. Dostęp do praktycznie nieograniczonej, bezkształtnej wirtualnej przestrzeni publicznej, gdzie każdy z nas może przechowywać swoje dane, sprawił, że nie musimy się już martwić o miejsce dla tego, co pragniemy zachować. Gdy archiwalna przestrzeń znacznie się poszerzyła, okazało się, że znajduje się w niej również miejsce dla tego, co do tej pory było z niej wykluczane jako nieistotne i nieważne. Miejsce magazynowania dokumentów zgodnie z teorią Derridy wpływa na kształt oraz treść zgromadzonych w nim informacji. Współczesne archiwum zdolne jest ocalić zdecydowanie więcej materiałów, dlatego znajdziemy w nim zdecydowanie więcej resztek i pozostałości, dla których wreszcie znalazło się miejsce, a te jeszcze niedawno miały status jedynie nic nieznaczących śmieci.

\section{Resztki, fragmenty i pozostałości}

Wydaje się, że kino można potraktować jako archiwum, które posługując się jednocześnie ruchomym obrazem i dźwiękiem, prawdopodobnie w największym stopniu stara się zrealizować ludzkie dążenie do zatrzymywania, ocalania oraz, co najważniejsze, do odtwarzania uciekającej wciąż w przeszłość teraźniejszości. Związek filmów z pragnieniem podkreśla m.in. Slavoj Žižek, który w Z-boczonej historii kina twierdzi, że kino jest najbardziej perwersyjnym rodzajem sztuki, gdyż nie daje nam wcale tego, czego pragniemy, lecz uczy nas pragnąc $c^{14}$.W kontekście rozważań słoweńskiego filozofa to właśnie filmy

13 Zob. J. Derrida Archive Fever..., s. 10.

14 Por. Z-boczona historia kina (reż. Sophie Fiennes, 2006): „Cinema is the ultimate pervert art. It doesn't give you what you desire - it tells you how to desire". 
z gatunku found footage najlepiej potrafiłyby nauczyć swoich widzów tęsknoty za tym, co odeszło bezpowrotnie.

Jednym z najbardziej zadłużonych w przeszłości reżyserów, jeśli chodzi o kino fabularne, jest bez wątpienia kanadyjski twórca Guy Maddin. Jego niezwykle dynamiczne, eksperymentalne i zarazem głęboko nostalgiczne kino sięga do czasów minionych, nie tylko podejmując autobiograficzne wątki dzieciństwa (Piętno na umyśle!', Moje Winnipeg), ale również odwołując się do anachronicznych filmowych form ${ }^{15}$. Maddin przyzwyczaił już swoich widzów do tego, że jego ulubionym okresem w historii filmu jest kino nieme, gdyż to właśnie do jego estetyki najczęściej nawiązuje. Jego surowe czarno-białe obrazy wypełnione są charakterystycznymi planszami z napisami, których rytmiczne pojawianie się i znikanie w ciekawy sposób kształtuje filmową dynamikę. Po kilku ostatnich mniej spektakularnych produkcjach kanadyjski reżyser powrócił na ekrany światowych kin w nieprzeciętnej, zjawiskowej wręcz formie, najnowszym obrazem Zakazany pokój (2014).

Maddin porzuca dotychczasową surową czarno-białą estetykę zapożyczoną z kina niemego na rzecz rozwarstwiających się barw oraz blaknącego koloru, co okazuje się niezwykle trafnym wyborem celuloidowego fetyszysty. Film nawiązuje w ten sposób do stylistyki found footage, gdyż szczątki, skrawki, urywki odgrywają tutaj główną rolę, co więcej, tworzą niesamowite oraz niezapomniane doświadczenie estetyczne. Reżyser za pomocą różnorodnych środków artystycznych typowych dla starych, rozkładających się taśm filmowych, imituje archiwalny styl (przeskoki poszczególnych klatek, zabrudzenia, rozmycia, wstrząsy, zadrapania, szumy i zakłócenia w warstwie dźwiękowej). Dzięki tym zabiegom udaje mu się ukazać twórczą siłę rozkładu, która przez cały czas trwania filmu nie przestaje fascynować i zadziwiać. Opowiadane przez Maddina historie, zlepione $\mathrm{z}$ fragmentów, pojawiają się przed widzami i jednocześnie rozpadają się na ich oczach. Kanadyjski reżyser swobodnie przemieszcza się po rozmaitych stylach i gatunkach (film edukacyjny, przygodowy, horror, romans itp.), natomiast głównym tematem jego filmu jest miłość do kina oraz jego opowieści. Tytułowy zakazany pokój okazuje się miejscem filmowej rozkoszy, jest przestrzenią punktów kulminacyjnych, łączących ze sobą wszystkie historie, które wprawia w ruch celuloidowe libido.

Zakazany pokój przypomina niesamowitą, dziwaczną podróż przez archiwum z obłąkanym przewodnikiem. Jednak głównym zadaniem, jakie sobie

15 Zob. G. Maddin, K. Mikurda, M. Oleszczyk Kino wykolejone. Rozmowy z Guyem Maddinem, Korporacja Ha!art, Kraków 2009. 
stawia, jest przedstawienie, a tym samym odzyskanie zagubionych opowieści, które nigdy nie istniały, gdyż nikt nie zdecydował się ich przenieść na ekran. Maddin tym samym jako pierwszy filmowiec w historii kina nie tyle stara się wskrzesić nieistniejącą już przeszłą rzeczywistość, ile upomina się o utracone fikcje, pragnąc je zarejestrować, ocalić przed zapomnieniem. Zakazany pokój stanowi przede wszystkim niezwykły i zarazem niespodziewany gest troski, jaką reżyser otacza obrazy, które bez jego pomocy nigdy by nie powstały, nie ujrzały światła dziennego. Trzeba przyznać, że Maddin ocala naprawdę marginalne filmy, opowiadające zbyt niepoważne albo zbyt dziwaczne historie, żeby mogły znaleźć pewne miejsce w archiwum, są one raczej filmowymi odpadkami, jakie wyrzuca się z historii kina już na etapie powstawania scenariusza.

Zakazany pokój przyjmuje postać dobrej nowiny, stanowi nadzieję dla wszystkich niechcianych i marginalizowanych do tej pory opowieści. Dlatego nic w tym dziwnego, że rozpoczyna się cytatem z Ewangelii według św. Jana: „A gdy się nasycili, rzekł do uczniów: «Zbierzcie pozostałe ułomki, aby nic nie zginęło»" (J 6,12). Reżyserska praca Maddina rzeczywiście w pewnym sensie przypomina zbawczą misję, dążącą do ocalenia resztek, które jednak do samego końca zachowują swoją pierwotną fragmentaryczność i odrębność. Niespokojna dynamika filmu, gdzie prawie każda klatka wyrywa się i oddziela od reszty, sprawia, że nie jesteśmy w stanie również scalić różnorodnych historii, które zostają przedstawione za pomocą strzępów, dlatego też nie zostają wchłonięte i unicestwione przez zgubne dążenie do całości.

Filmy found footage nie tylko starają się ukazać fragmentaryczną wizję rzeczywistości, ale też w niezwykły sposób dowartościowują resztki, postrzegane do tej pory zawsze jako niepełne, wybrakowane i nikomu niepotrzebne efekty uboczne kultury. Podobną fascynację skrawkami spotykamy również u Pierre'a Léona w Phantom Power (2014). Jego film również rozpoczyna się niezwykle wymownym mottem, pochodzącym z dramatu Romeo i Julia Williama Shakespeare'a: „Daj mi Romea, a po jego zgonie / Rozsyp go w gwiazdki! A niebo zapłonie / Tak, że się cały świat w tobie zakocha / I czci odmówi słońcu"16. Cytat w dość jasny sposób pokazuje, że śmierć całości jest koniecznym warunkiem różnorodności i wszelkiej twórczości, opierającej się raczej na rozkładzie niż dążeniu do jedności. Jeśli interpretować go w duchu Derridy,

16 Por. W. Shakespeare Romeo i Julia, przeł. J. Paszkowski, PIW, Warszawa 1975, (akt 3, scena 2). "Take him and cut him out in little stars, / And he will make the face of heaven so fine / That all the world will be in love with night / And pay no worship to the garish sun". 
wówczas można stwierdzić, że jedynie pod nieobecność archonta, strażnika sensu, archiwum może utracić swoją przytłaczającą, monolityczną strukturę i rozlać się w nieskończoną liczbę heterogenicznych opowieści. Miłość w tym wypadku paradoksalnie nie wiąże się z procesem jednoczenia tego, co do tej pory pozostawało osobne i rozdzielone, lecz okazuje się sprzymierzona z siłą rozkładu oraz podziału. Blask słońca, uznawanego za ideał jedności, zostaje przyćmiony przez wielość małych gwiazd, emitujących słabe światło, lecz to właśnie one od tej pory budzą nasz podziw, miłość i fascynację. Twórczość Guya Maddina zazwyczaj jest określana mianem obsesyjnego kina pragnienia. Kanadyjski reżyser tym razem nie kryje się ze swoją miłością i namiętnością do resztek, szczątków i fragmentów opowieści, a te są najpiękniejsze wówczas, gdy każda z nich rozchodzi się w swoją własną stronę.

\section{Twórcza siła rozkładu}

Za jednego z najwybitniejszych twórców found footage można bez najmniejszego wahania uznać Billa Morrisona, gdyż to właśnie za jego sprawą ten gatunek filmowy znalazł swoje niekwestionowane miejsce w galeriach sztuki współczesnej" ${ }^{17}$. Amerykański artysta nie kryje, że jednym z jego głównych źródeł inspiracji była filmowa trylogia „Qatsi” Godfreya Reggio (Koyaanisqatsi, Powaqqatsi i Naqoyqatsi), gdzie zamiast słów można usłyszeć minimalistyczną ścieżkę dźwiękową Philipa Glassa. Podobnie u Morrisona muzyka stanowi fundamentalną część artystycznego projektu, to ona powstaje zawsze jako pierwsza i dlatego warunkuje dalszy proces twórczy. Brak dźwięków oryginalnych, pochodzących z używanych przez reżysera materiałów filmowych, podkreśla radykalną nieobecność tego, co zostaje przez niego przedstawione jedynie w postaci śladu. Muzyka wprowadza iluzję ponownej obecności minionego świata, wprowadza chwilowe ożywienie, tchnienie życia w martwe od dawna ciało.

Morrison uzyskał rozgłos w świecie filmowym za sprawą niezwykłego filmu Decasia (2002), którego nazwa powstała przez połączenie dwóch słów decay (gnić, rozpadać się, psuć) oraz fantasia (fantazja). Prezentowane obrazy koncentrują się głównie na przedstawieniach ekstatycznego wyjścia poza swoje ciało, czyli najbardziej uniwersalnego rozdzielenia, rozkładu pojmowanego jako oddzielenie duszy od ciała. Wiele scen ukazuje po prostu ekstazę

17 Wystarczy wspomnieć chociażby o niedawnej retrospektywnej wystawie „Bill Morrison: Compositions" (14.10-21.11.2014) w The Museum of Modern Art w Nowym Jorku. 
religijną, modlitwę, taniec, śmiech, procesy parowania oraz wzlatywania, jak również momenty uwodzenia i napięcia erotycznego, pozwalające przez chwilę oderwać się od rzeczywistości. Charakterystyczna i trudna do opisania estetyka nie spełnia w tym przypadku tylko funkcji ornamentu, lecz doskonale współgra z treścią, którą współtworzy. Filmowe kadry dosłownie gniją na naszych oczach, rozpływają się i rozpadają w taki sposób, że często niezwykle trudno rozpoznać, co właściwie się na nich znajduje.

Amerykański artysta nawet przez chwilę nie próbuje odzyskać i odrestaurować idyllicznego, utopijnego obrazu utraconej przeszłości, lecz oferuje widzom jej powrót zza grobu jako nieumarłej (undead). Wszystko, co powraca z martwych, zupełnie jak w przypadku Smętarza dla zwierzaków Stephena Kinga,jest już zawsze niepokojąco inne, zatrważająco niepodobne. Powracający są zawsze złowieszczy, podobnie jak w warstwie językowej słowo "smętarz" nigdy nie będzie tym samym co „cmentarz"18. Oglądając filmy Morrisona, mamy do czynienia z powrotem archiwalnych zombie, obserwujemy rozkładające się ciało umarłej, zdeformowanej kultury, budzące jednocześnie sprzeczne uczucia: wstręt i zachwyt, obrzydzenie i fascynację ${ }^{19}$. Poszczególne kadry filmu przez ogromną ilość uszkodzeń spowodowanych niszczycielską działalnością czasu wprowadzają nieodparte wrażenie materialności samego archiwum oraz namacalności rozpadających się obrazów.

Narodziny zostają zastąpione lub utożsamione przez Morrisona z kreatywnym, procesem rozkładu, zadziwiającą i wykrzywiającą wszystko niezwykle produktywną deformacją. Gdy doskonale znane i rozpoznawane przez nas formy w momencie dezintegracji przyjmują zupełnie nowe, egzotyczne kształty, prace amerykańskiego reżysera przypominają malowane przez niego obrazy. Dlatego w Decasii odnajdziemy wiele odniesień i nawiązań do koła, symbolizującego powtarzający się w nieskończoność cykl składania oraz rozkładu. Film rozpoczyna się i kończy sceną tańczącego derwisza, który zatacza kręgi, a jego krążenie oraz sam proces zmiany staje się jednocześnie jedynym stałym punktem rzeczywistości. Świat wokół niego wiruje, ale i on sam, obracając się wkoło, podlega nieustannej transformacji.

Cykliczny taniec derwisza, który jeszcze przez chwilę próbuje opierać się nadciągającej sile rozkładu, przyprawia o egzystencjalny zawrót głowy,

18 Zob. J. Castricano, Cryptomimesis: The Gothic and Jacques Derrida's Ghost Writing, Montreal 2001, s. 55. 
doskonale znany z twórczości W.G. Sebalda ${ }^{20}$. Gdyby autor Pierścieni Saturna był biegły w sztuce filmowej, prawdopodobnie właśnie tak wyglądałyby jego obrazy. Obrazy Morrisona okazują się niezwykle ruchliwe, przedstawiają żywioł czasu, który niczym wiatr w służbie entropii podważa stabilność oraz trwałość teraźniejszości i każdego „teraz”. Decasia uświadamia nam, że zazwyczaj za wszelką cenę nie chcemy zdawać sobie sprawy z toczącego każdą chwilę rozkładu. Jej bohaterowie, wykonując zwykłe czynności, są zupełnie nieświadomi tego, że coś im zagraża, a nad ich głowami ma miejsce egzystencjalna wichura, trawiąca wszystko, co spotyka na swojej drodze. Film Morrisona pokazuje, że nasza codzienna rzeczywistość była do tej pory przedstawiana niezwykle statycznie, i wskazuje na czas jako główny motor nieustannych zmian. To właśnie jego destrukcyjnemu działaniu można się jedynie na chwilę przeciwstawić.

Jaki jest w takim razie sens oraz status pozostałości w entropijnym świecie, zaprojektowanym przez Billa Morrisona? Twórcy Decasii udało się to, co do tej pory wydawało się trudne lub całkowicie niemożliwe do wykonania, czyli w niezwykle sugestywny sposób przedstawić zagładę²1. Resztka w jego filmach odgrywa rolę głównego bohatera, ocalonego śmiertelnika, czegoś, co przetrwało, oparło się unicestwieniu i jeszcze przez chwilę wiedzie swój kruchy, zmienny, wiecznie zagrożony żywot. Obecność rozkładających się fragmentów w filmach found footage jest przede wszystkim świadectwem nieustannie dokonującej się w sąsiedztwie życia zagłady. Natomiast resztki są po prostu świadkami unicestwiającej działalności czasu, niewidocznego niszczyciela, niepozostawiającego żadnego śladu po swojej zbrodniczej działalności, pracującego zawsze w ukryciu i w milczeniu.

Dość dobrze widać ten proces w najnowszym filmie amerykańskiego twórcy Beyond Zero: 1914-1918 (2014), gdzie znów próbuje dokonać rzeczy niemożliwej, czyli przedstawić coś niewyobrażalnie strasznego, wydawałoby się zupełnie nieprzedstawialnego. Reżyser stara się zdać sprawę z koszmaru I wojny światowej, która niczym destrukcyjna siła czasu pozostawiła po sobie jedynie ludzkie strzępy, fragmenty, wraki i cienie. Wkrótce okazuje się, że wojenne zdjęcia nie zdają wcale sprawy z dawnego konfliktu zbrojnego, lecz przedstawiają odwieczną ludzką walkę z czasem, który nieustannie pożera i podważa naszą teraźniejszość. Filmowa rzeczywistość Morrisona, podobnie

Zob. W. G. Sebald, Czuję, zawrót głowy, przeł. M. Łukasiewicz, Warszawa 2010. 
zresztą jak nasza codzienność, zarażona jest zmiennością, rozkładem oraz wynikającą z nich różnorodnością. Ludzkie życie byłoby w takim razie wojną wypowiedzianą entropii, którą z różnym skutkiem każdego dnia próbuje powstrzymać i zawiesić chociaż na chwilę.

Jeszcze jednym niezwykle ciekawym projektem found footage w wydaniu Morrisona jest krótki film Re: Awakenings (2013). Tym razem reżyser decyduje się opowiedzieć o niezbadanej do tej pory fali śpiączki (encephalitis lethargica), która rozprzestrzeniała się po świecie i zbierała swoje żniwo w latach 20. XX wieku. Wielu pacjentów po zapadnięciu na tę tajemniczą chorobę umarło, natomiast niektórzy z nich pozostawali uśpieni, znajdując się przez długie lata w dziwnym stanie zawieszenia między życiem i śmiercią. Gdy w 1969 roku doktor Oliver Sacks rozpoczął pracę w jednym z domów dla nieuleczalnie chorych, znajdującym się na Bronksie, okazało się, że przebywa w nim aż 8o pacjentów cierpiących na ten rodzaj śpiączki. Rozpoczął eksperymentalną kurację substancją o nazwie „L-dopa”, która okazała się niezwykle skuteczna i przyniosła zupełnie nieoczekiwane efekty. Wegetujący do tej pory chorzy w 1973 roku pod wpływem nowego lekarstwa nagle wybudzili się i powrócili do swoich sił. Ten zaskakujący zwrot akcji nie trwał zbyt długo, po krótkim okresie przebudzenia ich sprawność pogorszyła się, powodując frustrację pacjentów, jednak warto dodać, że nigdy już nie powrócili do stanu śpiączki.

Morrison wykorzystuje w swoim filmie archiwalne nagrania amerykańskiego lekarza. Pokazuje widzom objawy pacjentów przed podaniem cudownego lekarstwa oraz tuż po jego zastosowaniu, gdy chorzy zachowują się jakby nagle wstali z martwych. Powoli wydobywają się z całkowitego otępienia, wykonując dziwne, nieskoordynowane i niewprawne ruchy. Komiczne i jednocześnie niesamowite gesty przypominają powrót żywych trupów albo przebudzenie zombie, którzy stracili płynność poruszania się. Ten krótki i niepozorny film jest szczególnie ważny dla twórczości found footage, gdyż doskonale ukazuje sposób działania amerykańskiego twórcy. Reżyser postępuje $\mathrm{z}$ archiwalnym materiałem podobnie jak Sacks ze swoimi podopiecznymi, którzy budzą się po prawie 50 latach uśpienia. Morrison wydobywa zamrożoną przez dekady w archiwum rzeczywistość i ożywia ją, wydobywa na światło dzienne przetrwalniki, resztki ocalałe z choroby zwanej przemijaniem. Warto dodać, że, tak jak w przypadku nieuleczalnie chorych, jest to tylko chwilowe przebudzenie przeszłości, gdyż nie da się jej w żaden sposób uobecnić utrwalić, czy też całkowicie uchronić przed przemijaniem. Ten idylliczny, utopijny stan pozornego odzyskania przeszłości i wskrzeszenia tego, co minione, nigdy nie trwa długo. 


\section{(Nie)śmiertelność obrazu cyfrowego}

Jedyną nadzieją, jaką można było do tej pory zaproponować obrazom zagrożonym wymarciem i rozkładem, była ich konserwacja oraz umieszczenie materiału audiowizualnego na nośniku cyfrowym, obiecującym skuteczną ochronę przed utratą jakości oraz przemijaniem, czyli - wieczne trwanie. Współczesna kultura alternatywna na różne sposoby wskazuje na iluzoryczność oraz tymczasowość projektu utrwalania kultury, dramatycznych prób wyjęcia jej spod destrukcyjnego działania czasu. Jedną z krytycznych prac artystycznych związanych z rozkładem i uśmiercaniem obrazu cyfrowego jest cykl Lossless (2009), którą zaprojektowali Rebecca Baron oraz Douglas Goodwin.

Tytuł serii nawiązuje do bezstratnej (lossless) kompresji danych typowej dla kultury cyfrowej, oferującej jej użytkownikom życie bez doświadczenia straty. Jej reżyserzy postanowili udowodnić oraz pokazać, że utrata dotyka również formatu cyfrowego i jest niemniej bolesna, jak w przypadku np. kultury analogowej. Lossless \#2 to zdeformowana i skrócona do trzech minut wersja osiemnastominutowego filmu Mai Deren Meshes of the Afternoon (1943). Artyści postanowili pobrać plik wideo z Internetu, a warto wiedzieć, że w przypadku korzystania z technologii Peer to Peer plik zostaje zazwyczaj zapisany na dysku w postaci fragmentów, a te są następnie łączone w całość. W tym wypadku pobieranie pliku zostało zakłócone i przerwane, dlatego film musiał zostać utworzony z niepasujących do siebie elementów, zakłócających doświadczenie całości. Zniekształcenie polega na zlewaniu się ze sobą rozpikselowanych obrazów, które przenikają się i nakładają się na siebie nawzajem, tworząc tym samym nieskończoną ilość śladów oraz powidoków. Po obejrzeniu całej serii Lossless nie mamy wątpliwości co do tego, że świat cyfrowy również jest materialny oraz śmiertelny, jak wszystko zanurzone w czasie i przestrzeni podlega rozkładowi.

Rozpikselowany obraz nie jest wyłącznie domeną gatunku found footage, lecz we współczesnym kinie pełni funkcje krytyczną. Jednym z filmów, który pełnymi garściami czerpie z estetyki pikseli jest Wideofilia (2015), psychodeliczny i bezkompromisowy w przyjętej przez siebie formie obraz w reżyserii Juana Daniela F. Molero. Ten cierpki, by nie powiedzieć „kwaśny” portret globalnego społeczeństwa opowiada o rozpikselowanym doświadczeniu współczesności. Wideofilia jest prawdopodobnie pierwszym filmem w historii kina, który czerpiąc obficie z estetyki YouTube, z ogromnym rozmachem miesza ze sobą rzeczywistość filmową i internetową. Peruwiański reżyser za pomocą barwnych pikseli oraz klasycznych memów kreśli prawdziwie narkotyczne 
wizje, gdzie substancją uzależniającą jest sam obraz, który można przedawkować. Dość pesymistyczny w swej wymowie film okazuje się jednak doskonałym przykładem rzeczywistości wielowarstwowej, hybrydycznej, gdzie podział na to, co realne i wirtualne, nie ma już żadnego sensu. Przez swoją nietypową estetykę zwiastuje zmierzch tradycyjnego kina offline oraz oferuje upragnione doświadczenie zanurzenia, jakie można porównać jedynie do wydzielania się strumienia endorfin w momencie podłączania się do Internetu, ekstatycznego bycia online.

Skąd w takim razie bierze się nasza fascynacja fragmentarycznym doświadczeniem rzeczywistości? Postmodernistyczne odejście od fascynacji całością oraz ujawnienie jej przemocy sprawiło, że współcześnie możemy bez przeszkód koncentrować się na fragmentach, które nie przestają nas ciekawić i fascynować. Śmierć jedności pozwoliła zająć się resztkami, jakie po niej pozostały. Jedną z odpowiedzi na pytanie dlaczego to właśnie marginalne ślady oraz pozostałości są tak bardzo interesujące, okazuje się zmiana, jaka nastąpiła w samym pojęciu archiwum. Prawie nieograniczona wirtualna przestrzeń, w jakiej możemy dzisiaj przechowywać nasze mniej lub bardziej cenne dane, sprawiła, że archiwum przestało być wykluczające i hierarchicznie ustrukturyzowane. Osłabienie roli archontów, zajmujących się do tej pory jego porządkowaniem wywołało niezwykle twórcze podejście do przeszłości, gdyż nikt nie posiada już odpowiedniej mocy, aby strzec jej poprawnej reprodukcji. Natomiast innym, lecz nie mniej ważnym powodem, dla którego otaczamy troską i opieką nieumarłe (undead) pozostałości kultury, jest nasze pragnienie ocalania tego, co najbardziej słabe i kruche, skazane na unicestwienie. Doskonale wiemy, że nie jesteśmy w stanie uobecnić przeszłości, możemy ocalać ją jedynie na chwilę, właśnie pod postacią resztek, ciągle jednak podejmujemy się tego zadania, przeciwstawiając się destrukcyjnemu działaniu czasu. 


\section{Abstract}

\section{Andrzej Marzec}

Fragments, Remnants and the Curse of the Archive: Nostalgia in the Culture of Found Footage

Why is today's culture so deeply attached to the past and focused on its own remnants, which have surprisingly quickly come to represent its creators' main field of interest? Marzec explores this question by drawing on Jacques Derrida's quasi-concept of the 'spectre' in order to interpret the artistic'found footage' work of Bill Morrison and other artists fascinated by the unusually creative and productive force of disintegration. This interesting film genre, forever gazing into the abyss of archival resources, not only brings to light the traces of a reality that has long ceased to exist - it also inspires a deep sense of nostalgia in its viewers and points to the faint presence of the past in the present, but above all, it fetishizes remnants.

\section{Keywords}

hauntology, found footage, archive, deconstruction, remnants 